\title{
IN MEMORIAM: PROF. ARNOLD J.P. TAMMES
}

On 21 August 1987 Professor Arnold Tammes died at the age of 80. In him we have lost one of the most prominent international lawyers in the Netherlands. From 1946 to 1977 he held the chair of public international law at the University of Amsterdam. For some time he was secretary to the Faculty and he succeeded in extending public international law in the curriculum of the Faculty. It was on his initiative that his chair of public international law was twice split at a time when it was still possible to create new chairs for new fields of law - possible, but not easy. First, a separate chair was created for the law of international organizations in 1963 and, secondly, an extraordinary chair for the international protection of human rights in 1968. Both chairs were taken by young lawyers (Henry Schermers and Theo van Boven, respectively) who gratefully remember Tammes for his support during their first years in office.

The weaker students considered Tammes a difficult teacher, but for the bright, interested students he could be very stimulating.

For many years Tammes represented the Netherlands at the Sixth Committee of the General Assembly of the United Nations of which he was Rapporteur in 1955. It was largely due to his personal initiatives that the Assembly discussed, during and after its 17th Session, the possibilities of establishing further organs charged with fact-finding which could be called in whenever the underlying facts of a dispute are unclear. Tammes was convinced that many disputes could easily be solved once the facts are established. Tammes was also a member of the Permanent Court of Arbitration and of the International Law Commission of the United Nations. In both organs he took his work very seriously and exerted considerable influence.

As a scholar Tammes was particularly systematic, original and forward looking. He wrote several books, and many articles which paved the way for, or indicated, new developments. His book on international organizations (1951, in Dutch) was the first book in that field, comparing the developments of the gradual federation of the German States with developments in modern international organizations. In 1959 he pleaded for a supreme council for factfinding (in Liber Amicorum François, in Dutch). In 1962 he wrote a leading article on the direct effect of international treaty obligations ('Een ieder verbindende verdragsbepalingen', NJB (1962)). His largest book appeared in 1966: a general textbook on public international law, in which he systematized international law in a way quite different from the traditional approach (Internationaal Publiekrecht (1966) 2nd ed. (1973)).

When Tammes left the University of Amsterdam on his 70th birthday the Netherlands International Law Review honoured him with a special double issue of essays on international law and relations (Vol. XXIV (1977)). In that issue there is also a biographical note on Tammes and a list of his principal publications. Of the 50 publications listed 42 are in Dutch and 8 in English. 
The most important of the latter is probably his course at the Hague Academy on 'Decisions of International Organs as a Source of International Law' (94 Hague Recueil (1958) II).

We will especially remember Tammes as a scholar who greatly contributed to the development of public international law in the Netherlands and he will be sadly missed.

Henry G. Schermers 